\title{
Trace Element Concentrations in the Expressed Prostatic Secretion of Normal and Hyperplastic Prostate
}

\author{
Vladimir Zaichick ${ }^{* 1}$ and Sofia Zaichick ${ }^{2}$ \\ ${ }^{1}$ Radionuclide Diagnostics Department, Medical Radiological Research Centre, Russia
}

${ }^{2}$ Department of Medicine, University of Illinois College of Medicine, USA

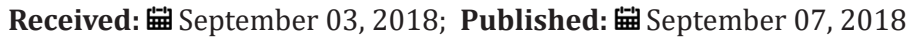

*Corresponding author: V Zaichick, Medical Radiological Research Centre, Korolyev St. 4, Obninsk 249036, Kaluga Region, Russia

\begin{abstract}
Objectives: Benign prostatic hyperplasia (BPH) is an internationally important health problem of the man, particularly in developed countries. The aim of this exploratory study was to evaluate whether significant changes in the levels of $\mathrm{Zn}$ and some other trace elements of prostatic fluid exist in the hyperplastic prostate.

Methods: Prostatic fluid levels of $\mathrm{Br}, \mathrm{Fe}, \mathrm{Rb}, \mathrm{Sr}$, and Zn were prospectively evaluated in 52 patients with BPH and 38 healthy male inhabitants. Measurements were performed using 109Cd radionuclide-induced energy dispersive X-ray fluorescent microanalysis. Prostatic fluid samples were divided into two portions. One was used for morphological study while the other was intended for trace element analysis.
\end{abstract}

Results: Mean values \pm standard error of means $(\mathrm{M} \pm \mathrm{SEM})$ for concentration $(\mathrm{mg} / \mathrm{L})$ of trace element in the expressed prostatic fluid (EPF) of normal prostate were: $\mathrm{Br} \pm 2.86 \pm 0.59$, Fe $8.30 \pm 1.42$, Rb 1.16 \pm 0.10 , Sr 1.27 \pm 0.17 , and $\mathrm{Zn} 598 \pm 34$. It was observed that in the EPF of hyperplastic prostate content of Rb significantly increased whereas content of Zn somewhat decreased in a comparison with those in the EPF of normal prostate.

Conclusions: There are significant changes in trace element contents and their relationships in the fluid of hyperplastic prostate. The alterations in levels of $\mathrm{Zn}$ and $\mathrm{Rb}$ in the EPF of hyperplastic prostate might demonstrate an involvement of these trace elements in etiology and pathogenesis of BPH. It was supposed that the changes of $\mathrm{Zn}$ and Rb levels in the EPF samples can be used as BPH markers.

Keywords: Benign prostatic hyperplasia; Prostatic Fluid; Trace Elements; Energy-Dispersive X-Ray Fluorescent Analysis

\section{Introduction}

Benign prostatic hyperplasia (BPH) is an internationally important health problem of the man, particularly in developed countries, and represents the most common urologic disease among of men after the age of fifty [1-3]. BPH is histologically defined as an overgrowth of the epithelial and stromal cells from the transition zone and peri-urethral area of prostate $[4,5]$. The excessive cell proliferation associated with BPH causes benign prostatic enlargement, bladder outlet obstruction, and lower urinary tract symptoms, which afflict the patients [3]. Incidence of histological BPH could be over $70 \%$ at 60 years old and over $90 \%$ at 70 years old $[1,6]$. To date, we still have no precise knowledge of the biochemical, cellular and molecular processes underlying the pathogenesis of BPH. Although the influence of androgens and estrogens has been demonstrated, hormonal factors alone may not fully explain BPH development [7,8].

Although the etiology of BPH is unknown, several risk factors including such micronutrients as trace element zinc (Zn), iron (Fe), selenium (Se) and some others have been identified [911]. Trace elements have essential physiological functions such as maintenance and regulation of cell function, gene regulation, 
activation or inhibition of enzymatic reactions, and regulation of membrane function. Essential or toxic (mutagenic, carcinogenic) properties of trace elements depend on tissue-specific need or tolerance, respectively [12]. Insufficient or excessive accumulation, as well as an imbalance of the trace elements may disturb the cell functions and may result in cellular degeneration, death or, on the contrary, intensive proliferation [13]. Thus, the findings of the excess or deficiency in trace elements and the perturbation in their relationships in benign hyperplastic tissue may highlight the role of these disturbances in etiology of BPH. Unfortunately, data on the effects of trace element intake on BPH risk are inconsistent and present a very mixed picture. However, there is evidence of mineral bioavailability decreases in the elderly [14]. Proponents of "theory of deficiency" think that due to lifestyle, eating and dietary habits, and physiological effects of aging, the elderly male population is normally predisposed to conditions of $\mathrm{Cu}, \mathrm{Fe}, \mathrm{Zn}$ and other antioxidant deficiency, which can increase their susceptibility to $\mathrm{BPH}[15,16]$.

In our previous studies a significant involvement of $\mathrm{Zn}$ and some trace element in the function of prostate was observed [1727]. Moreover, it was found that intracellular $\mathrm{Zn}$ and Ca excess is one of the main factors in the etiology of BPH and prostate cancer $[28,29]$. One of the main functions of prostate gland is a production of prostatic fluid [30] with extremely high concentration of $\mathrm{Zn}$ and some other chemical elements. The first finding of remarkable high level of $\mathrm{Zn}$ concentration in human expressed prostatic fluid (EPF) was reported in the beginning of 1960s [31]. Analyzing EPF expressed from prostate of 8 apparently healthy men aged 25-55 years it was found that $\mathrm{Zn}$ concentration varied in range from 300 to $730 \mathrm{mg} / \mathrm{L}$. After this finding several investigators have suggested that the measurement of $\mathrm{Zn}$ level in EPF may be useful as a marker of prostate secretory function $[32,33]$. It promoted a more detailed study of $\mathrm{Zn}$ concentration in EPF of healthy subjects and in those with different prostate diseases, including BPH [33,34]. A detailed review of these studies, reflecting the contradictions within accumulated data, was given in our earlier publication [34].

In present study it was supposed by us that apart from $\mathrm{Zn}$ the levels of some other trace elements in EPF have to reflect a disturbance of prostate function. Thus, this work had four aims. The first one was to present the design of the method and apparatus for micro analysis of $\mathrm{Br}, \mathrm{Fe}, \mathrm{Rb}, \mathrm{Sr}$, and $\mathrm{Zn}$ in the EPF samples using energy dispersive X-ray fluorescence (EDXRF) with radionuclide source $109 \mathrm{Cd}$. The second aim was to assess the $\mathrm{Br}$, $\mathrm{Fe}, \mathrm{Rb}, \mathrm{Sr}$, and $\mathrm{Zn}$ concentration in the EPF samples received from patients with normal and hyperplastic prostate gland. The third aim was to evaluate the quality of obtained results and to compare obtained results with published data. The last aim was to compare the concentration of $\mathrm{Br}, \mathrm{Fe}, \mathrm{Rb}, \mathrm{Sr}$, and $\mathrm{Zn}$ and intercorrelations of these trace elements in EPF samples of normal and hyperplastic prostate gland.

\section{Material and Methods}

Specimens of EPF were obtained from 38 men with apparently normal prostates (mean age \pm Standard Deviation - 59 \pm 11 years, range 41-82 years) and from 52 patients with BPH (mean age $63 \pm 6$ years, range $52-75$ years) by qualified urologists in the Urological Department of the Medical Radiological Research Centre using standard rectal massage procedure. In all cases the diagnosis has been confirmed by clinical examination and additionally in cases of BPH by morphological results obtained during studies of biopsy and resected materials. Subjects were asked to abstain from sexual intercourse for 3 days preceding the procedure. Specimens of EPF were obtained in sterile containers which were appropriately labeled. Twice twenty $\mu \mathrm{L}$ (microliters) of fluid were taken by micropipette from every specimen for trace element analysis, while the rest of the fluid was used for cytological and bacteriological investigations. The chosen $20 \mu \mathrm{L}$ of the EPF was dropped on 11.3 $\mathrm{mm}$ diameter disk made of thin, ash-free filter papers fixed on the Scotch tape pieces and dried in an exsiccator at room temperature. Then the dried sample was covered with $4 \mu \mathrm{m}$ SDacron film and centrally pulled onto a Plexiglas cylindrical frame (Figure 1).

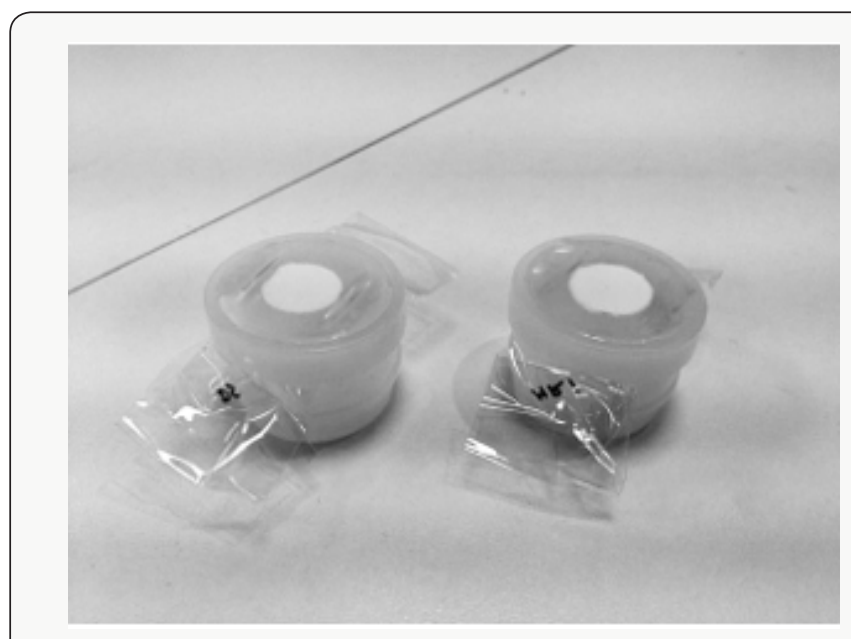

Figure 1: The dried samples of prostate fluid on filter paper disks fixed on the Scotch tape pieces centrally pulled onto a Plexiglas cylindrical frame.

To determine concentration of the elements by comparison with a known standard, aliquots of solutions of commercial, chemically pure compounds were used for a device calibration [35]. The standard samples for calibration were prepared in the same way as the samples of prostate fluid. Because there were no available liquid Certified Reference Material (CRM) ten sub-samples of the powdery CRM IAEA H-4 (animal muscle) were analyzed to estimate the precision and accuracy of results. Every CRM sub-sample weighing about $3 \mathrm{mg}$ was applied to the piece of Scotch tape serving as an adhesive fixing backing. An acrylic stencil made in the form of a thin-walled cylinder with $11.3 \mathrm{~mm}$ inner diameter was used to apply the sub-sample to the Scotch tape. The polished-end acrylic pestle which is a constituent of the stencil set was used for uniform 
distribution of the sub-sample within the Scorch surface restricted by stencil inner diameter. When the sub-sample was slightly pressed to the Scotch adhesive sample, the stencil was removed. Then the sub-sample was covered with $4 \mu \mathrm{m}$ Dacron film. Before the sample was applied, pieces of Scotch tape and Dacron film were weighed using analytical balance. Those were again weighed together with the sample inside to determine the sub-sample mass precisely.

The facility for radionuclide-induced energy dispersive X-ray fluorescence included an annular 109Cd source with an activity of $2.56 \mathrm{GBq}, \mathrm{Si}(\mathrm{Li})$ detector with electric cooler and portable multichannel analyzer combined with a PC. Its resolution was $270 \mathrm{eV}$ at the $6.4 \mathrm{keV}$ line. The facility functioned as follows. Photons with a $22.1 \mathrm{keV} 109 \mathrm{Cd}$ energy are sent to the surface of a specimen analyzed inducing the fluorescence $\mathrm{K}_{\alpha} \mathrm{X}$-rays of trace elements. The fluorescence irradiation got to the detector through a $10 \mathrm{~mm}$ diameter collimator to be recorded.

The duration of the $\mathrm{Zn}$ concentration measurement was 10

\section{Results}

Table 1: EDXRF data of $\mathrm{Br}, \mathrm{Fe}, \mathrm{Rb}, \mathrm{Sr}$, and $\mathrm{Zn}$ contents in the IAEA H-4 (animal muscle) reference material compared to certified values (mg kg-1, dry mass basis).

\begin{tabular}{|c|c|c|c|c|}
\hline Element & \multicolumn{3}{|c|}{ Certified values } & This work results \\
\hline & Mean & $\mathbf{9 5 \%}$ confidence interval & Type & Mean \pm SD \\
\hline $\mathrm{Fe}$ & 49 & $47-51$ & $\mathrm{C}$ & $\mathbf{4} \pm 9$ \\
\hline $\mathrm{Zn}$ & 86 & $83-90$ & $\mathrm{C}$ & $5.0 \pm 1.2$ \\
\hline $\mathrm{Br}$ & 4.1 & $3.5-4.7$ & $\mathrm{C}$ & $22 \pm 4$ \\
\hline $\mathrm{Rb}$ & 18 & $17-20$ & $\mathrm{C}$ & $\mathrm{N}$ \\
\hline $\mathrm{Sr}$ & 0.1 & - & $\mathrm{N}$ & $<1$ \\
\hline
\end{tabular}

Mean - arithmetical mean, SD - standard deviation, C- certified values, N - non-certified values.

a) Table 1 depicts our data for 5 trace elements in ten sub-samples of CRM IAEA H-4 (animal muscle) and the certified values of this material.

Table 2: Some basic statistical parameters of $\mathrm{Br}, \mathrm{Fe}, \mathrm{Rb}, \mathrm{Sr}$, and $\mathrm{Zn}$ concentration (mg/L) in prostate fluid of health men and patients with $\mathrm{BPH}$.

\begin{tabular}{|c|c|c|c|c|c|c|c|c|c|}
\hline Condition & Element & Mean & SD & SEM & Min & Max & Median & Per. 0.025 & Per. 0.975 \\
\hline Norm & $\mathrm{Br}$ & 2.86 & 2.93 & 0.59 & 0.490 & 8.53 & 1.20 & 0.496 & 8.53 \\
\hline $41-82$ years & $\mathrm{Fe}$ & 8.30 & 7.62 & 1.42 & 1.27 & 39.8 & 7.33 & 1.29 & 23.5 \\
\hline $\mathrm{n}=38$ & $\mathrm{Rb}$ & 1.16 & 0.52 & 0.10 & 0.376 & 2.45 & 1.03 & 0.422 & 2.38 \\
\hline & $\mathrm{Sr}$ & 1.27 & 0.84 & 0.17 & 0.400 & 3.44 & 1.18 & 0.400 & 3.22 \\
\hline & $\mathrm{Zn}$ & 598 & 207 & 34 & 253 & 948 & 560 & 278 & 942 \\
\hline $\mathrm{BPH}$ & $\mathrm{Br}$ & 2.32 & 1.84 & 0.30 & 0.230 & 8.70 & 1.62 & 0.268 & 5.84 \\
\hline $52-75$ years & $\mathrm{Fe}$ & 11.5 & 10.8 & 1.8 & 1.06 & 54.1 & 9.31 & 1.09 & 38.9 \\
\hline $\mathrm{n}=52$ & $\mathrm{Rb}$ & 1.70 & 1.41 & 0.23 & 0.210 & 5.04 & 1.46 & 0.254 & 5.04 \\
\hline & $\mathrm{Sr}$ & 1.41 & 1.09 & 0.26 & 0.230 & 4.79 & 1.12 & 0.300 & 4.02 \\
\hline & $\mathrm{Zn}$ & 488 & 302 & 42 & 45.0 & 977 & 427 & 81.4 & 962 \\
\hline
\end{tabular}

M - arithmetic mean, SD - standard deviation, SEM - standard error of mean, Min - inimum value, Max - maximum value, Per. 0.025 - percentile with 0.025 level, Per. 0.975 - percentile with 0.975 level, DL - detection limit. 
b) Table 2 presents certain statistical parameters (arithmetic mean, standard deviation, standard error of mean, minimal and maximal values, median, percentiles with 0.025 and 0.975 levels) of the $\mathrm{Br}, \mathrm{Fe}, \mathrm{Rb}, \mathrm{Sr}$, and $\mathrm{Zn}$ concentrations in EPF of normal and hyperplastic prostate.

c) The comparison of our results with published data for $\mathrm{Br}, \mathrm{Fe}$, $\mathrm{Rb}, \mathrm{Sr}$, and $\mathrm{Zn}$ concentrations in EPF of normal and hyperplastic prostate. $[33,34,36-39]$ is shown in Table 3.

Table 3: Median, minimum and maximum value of means of $\mathrm{Br}, \mathrm{Fe}, \mathrm{Rb}, \mathrm{Sr}$, and $\mathrm{Zn}$ concentration $(\mathrm{mg} / \mathrm{L})$ in prostate fluid of health men and patients with $\mathrm{BPH}$ according to data from the literature.

\begin{tabular}{|c|c|c|c|c|c|}
\hline \multirow[t]{2}{*}{ Condition } & \multirow[t]{2}{*}{ El } & \multicolumn{3}{|c|}{ Published data [Reference] } & \multirow{2}{*}{$\begin{array}{c}\text { This work results } \\
\mathrm{M} \pm \mathrm{SD}\end{array}$} \\
\hline & & Median of means (n)* & Minimum of means $M$ or $M \pm S D,(n)^{* *}$ & Maximum of means $\mathrm{M} \pm \mathrm{SD},(\mathrm{n})^{* *}$ & \\
\hline \multirow[t]{5}{*}{ Norm } & $\mathrm{Br}$ & - & - & - & $2.86 \pm 2.93$ \\
\hline & $\mathrm{Fe}$ & - & - & - & $8.30 \pm 7.62$ \\
\hline & $\mathrm{Rb}$ & $2.26(1)$ & $2.26 \pm 1.28(18)[33]$ & $2.26 \pm 1.28(18)[33]$ & $1.16 \pm 0.52$ \\
\hline & $\mathrm{Sr}$ & - & - & - & $1.27 \pm 0.84$ \\
\hline & $\mathrm{Zn}$ & $453(19)$ & $47.1(-)[36]$ & $5185 \pm 3737(10)[37]$ & $598 \pm 207$ \\
\hline \multirow[t]{5}{*}{$\mathrm{BPH}$} & $\mathrm{Br}$ & - & - & - & $2.32 \pm 1.84$ \\
\hline & $\mathrm{Fe}$ & - & - & - & $11.5 \pm 10.8$ \\
\hline & $\mathrm{Rb}$ & $2.35(1)$ & $2.35 \pm 1.85(11)[33]$ & $2.35 \pm 1.85(11)[33]$ & $1.70 \pm 1.41$ \\
\hline & $\mathrm{Sr}$ & - & - & - & $1.41 \pm 1.09$ \\
\hline & $\mathrm{Zn}$ & $459(7)$ & $268(7)[38]$ & $9870 \pm 10130(11)[37]$ & $488 \pm 302$ \\
\hline
\end{tabular}

El - element, M - arithmetic mean, SD - standard deviation, $(n)^{*}$ - number of all references, $(n)^{* *}$ - number of samples.

d) The ratios of means and the differences between mean values of $\mathrm{Br}, \mathrm{Fe}, \mathrm{Rb}, \mathrm{Sr}$, and $\mathrm{Zn}$ concentrations in EPF of normal and hyperplastic prostate are presented in Table 4.

Table 4: Comparison of mean values $(\mathrm{M} \pm \mathrm{SEM})$ of $\mathrm{Br}, \mathrm{Fe}, \mathrm{Rb}, \mathrm{Sr}$, and $\mathrm{Zn}$ concentration $(\mathrm{mg} / \mathrm{L})$ in prostate fluid of health men and patients with $\mathrm{BPH}$.

\begin{tabular}{|c|c|c|c|c|c|}
\hline \multirow{2}{*}{ Element } & \multicolumn{4}{|c|}{ Age groups } & Ratios \\
\hline & Norm & BPH & Student's t-test $\boldsymbol{p}<$ & $\boldsymbol{U}$-test* $\boldsymbol{p}$ & BPH to Norm \\
\hline $\mathrm{Br}$ & $2.86 \pm 0.59$ & $2.32 \pm 0.30$ & 0.414 & $>0.05$ & 0.81 \\
\hline $\mathrm{Fe}$ & $8.30 \pm 1.42$ & $11.5 \pm 1.8$ & 0.171 & $>0.05$ & 1.39 \\
\hline $\mathrm{Rb}$ & $1.16 \pm 0.10$ & $1.70 \pm 0.23$ & $\mathbf{0 . 0 3 1}$ & $<\mathbf{0 . 0 1}$ & 1.47 \\
\hline $\mathrm{Sr}$ & $1.27 \pm 0.17$ & $1.41 \pm 0.26$ & 0.660 & $>0.05$ & 1.11 \\
\hline $\mathrm{Zn}$ & $598 \pm 34$ & $488 \pm 42$ & $\mathbf{0 . 0 4 4}$ & $<\mathbf{0 . 0 1}$ & 0.82 \\
\hline
\end{tabular}

$\mathrm{M}$ - arithmetic mean, SEM - standard error of mean, *Wilcoxon-Mann-Whitney U-test, bold - significant difference ( $\leq \leq 0.05)$

Table 5: Intercorrelations of pairs of the trace element concentration in prostate fluid of health men and patients with BPH $(r-$ coefficient of correlation).

\begin{tabular}{|c|c|c|c|c|c|c|}
\hline Tissue & Element & $\mathbf{B r}$ & $\mathbf{F e}$ & $\mathbf{R b}$ & $\mathbf{S r}$ & $\mathbf{Z n}$ \\
\hline Norm & $\mathrm{Br}$ & 1.0 & $0.714^{\mathrm{b}}$ & 0.178 & 0.172 & $-0.535^{\mathrm{b}}$ \\
\hline $41-82$ years & $\mathrm{Fe}$ & $0.714^{\mathrm{b}}$ & 1.0 & 0.148 & $0.410^{\mathrm{a}}$ & -0.241 \\
\hline $\mathrm{n}=38$ & $\mathrm{Rb}$ & 0.178 & 0.148 & 1.0 & -0.131 & -0.097 \\
\hline & $\mathrm{Sr}$ & 0.172 & $0.410^{\mathrm{a}}$ & -0.131 & 1.0 & 0.069 \\
\hline & $\mathrm{Zn}$ & $-0.535^{\mathrm{b}}$ & -0.241 & -0.097 & 0.069 & -0.070 \\
\hline $\mathrm{BPH}$ & $\mathrm{Br}$ & 1.0 & 0.209 & 0.213 & -0.075 & 0.040 \\
\hline $52-75$ years & $\mathrm{Fe}$ & 0.209 & 1.0 & 0.031 & -0.117 & 0.004 \\
\hline $\mathrm{n}=52$ & $\mathrm{Rb}$ & 0.213 & 0.031 & 1.0 & -0.117 & -0.0 \\
\hline
\end{tabular}

Statistically significant values with: a $p<0.01, b \mathrm{p}<0.001$ 
e) Table 5 contains results of inter-element correlation calculations (values of $\mathrm{r}$ - coefficient of correlation) including all trace elements identified in this work.

\section{Discussion}

Good agreement of the $\mathrm{Fe}, \mathrm{Zn}, \mathrm{Br}, \mathrm{Rb}$, and $\mathrm{Sr}$ contents analyzed by $109 \mathrm{Cd}$ radionuclide-induced EDXRF with the certified data of CRM IAEA H-4 (Table 2) indicate an acceptable accuracy of the results obtained in the study of trace elements of the prostate fluid presented in Tables 2-5. The mean values and all selected statistical parameters were calculated for 5 trace elements $(\mathrm{Br}$, $\mathrm{Fe}, \mathrm{Rb}, \mathrm{Sr}$, and $\mathrm{Zn}$ ) of trace element concentrations (Table 2). The concentrations of $\mathrm{Br}, \mathrm{Fe}, \mathrm{Rb}, \mathrm{Sr}$, and $\mathrm{Zn}$ were measured in all, or a major portion of EPF samples of normal and hyperplastic prostate. The mean of $\mathrm{Zn}$ concentration obtained for normal prostate fluid, as shown in Table 3, agrees well with median of means cited by other researches [31-32,36-38]. The mean of $\mathrm{Rb}$ concentration obtained for EPF agrees well with our data reported 37 years ago [33]. No published data referring to $\mathrm{Br}, \mathrm{Fe}$, and $\mathrm{Sr}$ concentrations in normal EPF were found. In the EPF samples of hyperplastic prostate our results were comparable with published data for $\mathrm{Rb}$ and $\mathrm{Zn}$ concentrations (Table 3). No published data referring to $\mathrm{Br}$, Fe, and Sr concentrations in EPF of patients with BPH were found.

A number of values for $\mathrm{Zn}$ concentrations in normal EPF were not expressed on a wet mass basis in the cited literature. Therefore, we calculated these values using the published data for water content in EPF -93.2\% [39].

From Table 4, it is observed that in EPF of hyperplastic prostate the concentrations of $\mathrm{Rb}$ is $47 \%$ higher whereas the concentrations of $\mathrm{Zn}$ is $18 \%$ lower than levels of these trace element in EPS of normal prostate. Inter-element correlations between trace elements are significantly altered in EPF of hyperplastic prostate as compared to their relationships in EPF of normal prostate (Table 5). In EPF of hyperplastic prostates some significant correlations between trace elements found in the EPF of control group are no longer evident but other correlations arise. For example, in the EPF of healthy males there is inverse correlation between $\mathrm{Zn}$ and $\mathrm{Br}$ and also direct correlation between $\mathrm{Fe}$ and $\mathrm{Br}$ (Table 5).

Thus, if we accept the relationships of trace element concentrations in EPF of males in the control group as a norm, we have to conclude that with a benign hyperplasia the relationships between trace elements in EPF significantly changed. No published data referring to correlations between trace elements concentrations in EPF of normal and hyperplastic prostate were found. The range of means of $\mathrm{Zn}$ concentration reported in the literature for normal EPF (from 47.1 to $5185 \mathrm{mg} / \mathrm{L}$ ) and for EPF of untreated hyperplastic prostate (from 268 to $9870 \mathrm{mg} / \mathrm{L}$ ) varies widely (Table 3). This can be explained by a dependence of Zn content on many factors, including age, ethnicity, mass of the gland, the BPH stage, and others. Not all these factors were strictly controlled in cited studies. Another and, in our opinion, leading cause of interobserver variability was insufficient quality control of results in these studies. In many reported papers EPF samples were dried at high temperature or acid digestion. There is evidence that by use of these methods some quantities of trace elements, including $\mathrm{Zn}$, are lost as a result of this treatment [40-42].

Characteristically, elevated or deficient levels of trace elements and electrolytes observed in EPF of hyperplastic prostate are discussed in terms of their potential role in the initiation, promotion, or inhibition of prostate cell proliferation. In our opinion, abnormal levels of many trace elements in EPF of hyperplastic prostate could be the consequence of benign transformation. Compared to other fluids of human body, the prostate secretion has higher levels of $\mathrm{Zn}$ and some other trace elements. These data suggest that these elements could be involved in functional features of prostate. Fast cell proliferation is accompanied by a suppression of their specific functional activity, which leads to a small reduction in the $\mathrm{Zn}$ content in EPF. Our findings show that the concentration of $\mathrm{Rb}$ is significantly higher whereas the concentration of $\mathrm{Zn}$ is somewhat lower in EPF of hyperplastic prostate as compared to their levels in EPF of normal prostate (Table 4). Thus, it is plausible to assume that levels of these trace elements in EPF can be used as BPH markers. However, this subjects needs in additional studies.

This study has several limitations. Firstly, analytical techniques employed in this study measure only five trace element $(\mathrm{Br}, \mathrm{Fe}, \mathrm{Rb}$, Sr and Zn) concentrations in EPF. Future studies should be directed toward using other analytical methods which will extend the list of chemical elements investigated in EPF of normal and hyperplastic prostate. Secondly, the sample size of BPH group was relatively small. It was not allow us to carry out the investigations of trace element contents in BPH group using differentials like stage of disease, dietary habits of healthy persons and patients with $\mathrm{BPH}$, and others. Despite these limitations, this study provides evidence on hyperplasia-specific $\mathrm{Rb}$ and $\mathrm{Zn}$ level alteration in EPF and shows the necessity the need to continue chemical element research of EPF in norm and prostatic diseases.

\section{Conclusion}

In this work, trace elemental measurements were carried out in the EPF samples of normal and hyperplastic prostate using nondestructive instrumental EDXRF micro method developed by us. It was shown that this method is an adequate analytical tool for the non-destructive determination of $\mathrm{Br}, \mathrm{Fe}, \mathrm{Rb}, \mathrm{Sr}$, and $\mathrm{Zn}$ concentration in the EPF samples of human prostate. It was observed that in the EPF of hyperplastic prostate content of $\mathrm{Rb}$ significantly increased whereas content of Zn somewhat decreased in a comparison with those in the EPF of normal prostate. In our opinion, the alterations in levels of $\mathrm{Zn}$ and $\mathrm{Rb}$ in the EPF of hyperplastic prostate might demonstrate an involvement of these trace elements in etiology and pathogenesis of BPH. It was supposed that the changes of $\mathrm{Zn}$ and $\mathrm{Rb}$ levels in the EPF samples can be used as BPH markers. 


\section{Declaration}

All studies were approved by the Ethical Committees of the Medical Radiological Research Centre, Obninsk. All procedures performed in studies involving human participants were in accordance with the ethical standards of the institutional and/or national research committee and with the 1964 Helsinki declaration and its later amendments or comparable ethical standards.

\section{Acknowledgements}

We are grateful to Dr Tatyana Sviridova, Medical Radiological Research Center, Obninsk for supplying EPF samples

\section{References}

1. Carter HB, Coffey DS (1990) The prostate: an increasing medical problem. Prostate 16(1): 39-48.

2. Garraway WM, Collins GN, Lee RJ (1991) High prevalence of benign prostatic hypertrophy in the community. Lancet 338(8765): 469-471.

3. Burnett AL, Wein AJ (2006) Benign prostatic hyperplasia in primary care: what you need to know. J Urol 175: S19-S24.

4. Shapiro E, Hartonto V, Lepor H (1992) Quantifying the soooth muscle content of the prostate using double-immunoenzymatic staining and color assisted image analysis. J Urol 147: 1167-1169.

5. Robert G, Descazeaud A, Nicolaïew N, Terry S, Sirab N, et al. (2009) Inflammation in benign prostatic hyperplasia: a 282 patients immunohistochemical analysis. Prostate 69(16): 1774-1780.

6. Gong EM, Gerber GS (2004) Saw palmetto and benign prostatic hyperplasia. Am J Chin Med 32(3): 331-338.

7. Lee KL, Peehl DM (2004) Molecular and cellular pathogenesis of benign prostatic hyperplasia. J Urol 172(5): 1784-1791.

8. Li W, Wu C-L, Febbo PG, Olumi AF (2007) Stromally Expressed c-Jun Regulates Proliferation of Prostate Epithelial Cells. The American Journal of Pathology 171(4): 1189-1198.

9. Tavani A, Longoni E, Bosetti C, Maso LD, Polesel J, et al. (2006) Intake of selected micronutrients and the risk of surgically treated benign prostatic hyperplasia: a case-control study from Italy. Eur Urol 50(3): 549-554.

10. Bravi F, Bosetti C, Dal Maso L, Talamini R, Montella M, et al. (2006) Food groups and risk of benign prostatic hyperplasia. Urology 67(1): 73-79.

11. Galeone C, Pelucchi C, Talamini R, Negri E, Dal Maso L, et al. (2007) Onion and garlic intake and the odds of benign prostatic hyperplasia. Urology 70(4): 672-676.

12. Zaichick V (2006) Medical elementology as a new scientific discipline. Radioanal Nucl Chem 269(2): 303-309.

13. Habib FK, Hammond GL, Lee JR, Dawson JB, Mason MK, et al. (1976) Metal-androgen interrelationships in carcinoma and hyperplasia of the human prostate. J Endocrinol 71(1): 133-142.

14. Vaquero MP (2002) Magnesium and trace elements in the elderly: intake, status and recommendations. J Nutr Health Aging 6(2): 147-153.

15. Mocchegiani E, Muaaioli M, Giacconi R (2000) Zinc, metallothioneins, immune responses, survival and ageing. Biogeront 1(2): 133-143.

16. Ekmekcioglu C (2001) The role of trace elements for the health of elderly individuals. Nahrung 45: 309-316.

17. Zaichick V (2004) INAA and EDXRF applications in the age dynamics assessment of $\mathrm{Zn}$ content and distribution in the normal human prostate. J Radioanal Nucl Chem 262: 229-234.
18. Zaichick V, Zaichick S (2013) The effect of age on $\mathrm{Br}, \mathrm{Ca}, \mathrm{Cl}, \mathrm{K}, \mathrm{Mg}, \mathrm{Mn}$, and $\mathrm{Na}$ mass fraction in pediatric and young adult prostate glands investigated by neutron activation analysis. Appl Radiat Isot 82: 145511.

19. Zaichick V, Zaichick S (2013) INAA application in the assessment of Ag, $\mathrm{Co}, \mathrm{Cr}, \mathrm{Fe}, \mathrm{Hg}, \mathrm{Rb}, \mathrm{Sb}, \mathrm{Sc}, \mathrm{Se}$, and $\mathrm{Zn}$ mass fraction in pediatric and young adult prostate glands. J Radioanal Nucl Chem 298(3): 1559-1566.

20.Zaichick V, Zaichick S (2013) NAA-SLR and ICP-AES Application in the assessment of mass fraction of 19 chemical elements in pediatric and young adult prostate glands. Biol Trace Element Res 156(1): 357-366.

21.Zaichick V, Zaichick S (2013) Use of neutron activation analysis and inductively coupled plasma mass spectrometry for the determination of trace elements in pediatric and young adult prostate. American Journal of Analytical Chemistry 4: 696-706.

22.Zaichick V, Zaichick S (2014) Relations of bromine, iron, rubidium, strontium, and zinc content to morphometric parameters in pediatric and nonhyperplastic young adult prostate glands. Biol Trace Element Res 157(3): 195-204.

23. Zaichick V, Zaichick S (2014) Relations of the neutron activation analysis data to morphometric parameters in pediatric and nonhyperplastic young adult prostate glands. Advances in Biomedical Science and Engineering 1(1): 26-42.

24.Zaichick V, Zaichick S (2014) Relations of the $\mathrm{Al}, \mathrm{B}, \mathrm{Ba}, \mathrm{Br}, \mathrm{Ca}, \mathrm{Cl}, \mathrm{Cu}$, $\mathrm{Fe}, \mathrm{K}, \mathrm{Li}, \mathrm{Mg}, \mathrm{Mn}, \mathrm{Na}, \mathrm{P}, \mathrm{S}, \mathrm{Si}, \mathrm{Sr}$, and $\mathrm{Zn}$ mass fractions to morphometric parameters in pediatric and nonhyperplastic young adult prostate glands. BioMetals 27(2): 333-348.

25.Zaichick V, Zaichick S (2014) The distribution of 54 trace elements including zinc in pediatric and nonhyperplastic young adult prostate gland tissues. Journal of Clinical and Laboratory Investigation Updates 2(1): 1-15.

26. Zaichick V, Zaichick S (2014) Androgen-dependent chemical elements of prostate gland. Androl Gynecol: Curr Res 2:2.

27.Zaichick V, Zaichick S (2015) Differences and relationships between morphometric parameters and zinc content in nonhyperplastic and hyperplastic prostate glands. BJMMR 8(8): 692-706.

28. Zaichick V, Zaichick S Wynchank S (2016) Intracellular zinc excess as one of the main factors in the etiology of prostate cancer. J Anal Oncol 5(3): 124-131.

29. Zaichick V, Zaichick S, Rossmann M (2016) Intracellular calcium excess as one of the main factors in the etiology of prostate cancer. AIMS Molecular Science 3(4): 635-647.

30.Zaichick V (2014) The prostatic urethra as a Venturi effect urine-jet pump to drain prostatic fluid. Med Hypotheses 83(1): 65-68.

31. Mackenzie AR, Hall T, Whitmore WFJr (1962) Zinc content of expressed human prostate fluid. Nature (London) 193(4810): 72-73.

32. Marmar JL, Katz S, Praiss DE, DeBenedictis TJ (1980) Values for zinc in whole semen, fraction of split ejaculate and expressed prostatic fluid. Urology 16(5): 478-480.

33.Zaichick V, Tsyb A, Dunchik VN, Sviridova TV (1981) Method for diagnostics of prostate diseases. Certificate of invention No 997281 (30.03.1981), Russia.

34. Zaichick V, Sviridova T, Zaichick S (1996) Zinc concentration in human prostatic fluid: normal, chronic prostatitis, adenoma, and cancer. Int Urol Nephrol 28(5): 687-694.

35.Zaichick V (1995) Applications of synthetic reference materials in the medical Radiological Research Centre. Fresenius J Anal Chem 352: 219223.

36. Burgos MN (1974) Biochemical and functional properties related to sperm metabolism and fertility. In: Male accessory sex organs (Brandes D, editor). New York: Academic Press, pp.151-160. 
37. Gómes Y, Arocha F, Espinoza F,Fernandez D, Vásquez A, et al. (2007) Niveles de zinc en líquido prostático de pacientes con patologías de próstata. Invest Clin 48(3): 287-294.

38. Romics I, Bach D (1991) Zn, Ca and Na levels in the prostatic secretion of patients with prostatic adenoma. Int Urol Nephrol 23(1): 45-49.

39. Huggins C, Scott W., Heinen JH (1942) Chemical composition of human semen and of the secretion of the prostate and seminal vesicles. Amer J Physiol 136(3): 467-473.

40. Zaichick V (1997) Sampling, sample storage and preparation of biomaterials for INAA in clinical medicine, occupational and environmental health. In: Harmonization of Health-Related Environmental Measurements Using Nuclear and Isotopic Techniques. Vienna: IAEA, pp. 123-133.

41. Zaichick V, Zaichick S (1997) A search for losses of chemical elements during freeze-drying of biological materials. J Radioanal Nucl Chem 218(2): 249-253.

42. Zaichick V (2004) Losses of chemical elements in biological samples under the dry aching process. Trace Elements in Medicine 5(3): 17-22.

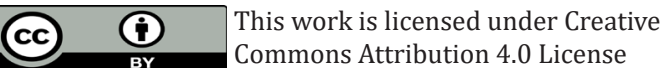

To Submit Your Article Click Here:

Submit Article

DOI: $10.32474 / J U N S .2018 .01 .000112$

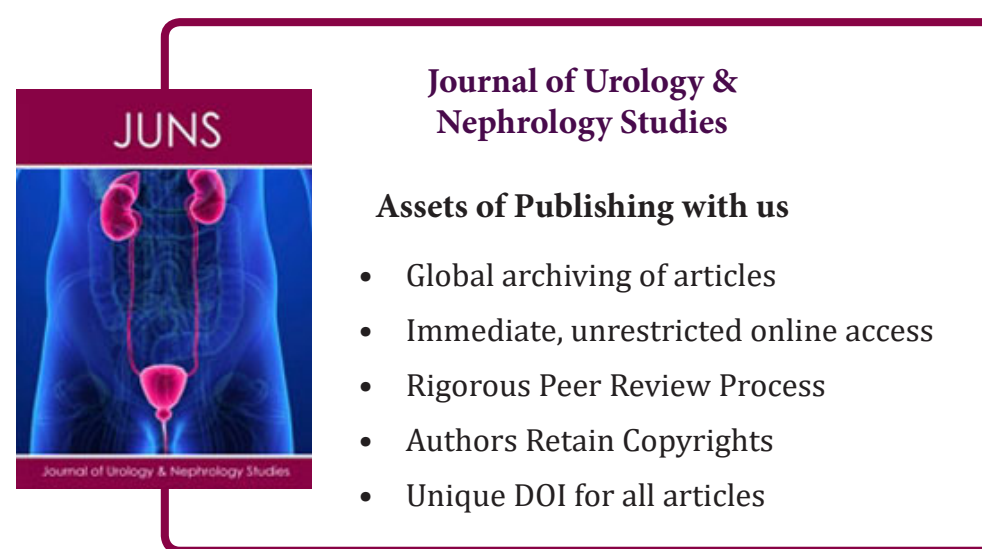

